\title{
Gambaran Tingkat Pengetahuan dan Kepatuhan Pada Pasien Tuberkulosis di Rumah Sakit Umum Provinsi NTB Periode Juli- Agustus 2019.
}

\author{
Baiq Nurbaety ${ }^{a, 1^{*}}$, Abdul Rahman Wahid ${ }^{a, 2}$, Ekarani Suryaningsiha ${ }^{a, 3}$ \\ a,1,2 Dosen Program Studi Diploma Tiga Farmasi, Universitas Muhammadiyah Mataram, Mataram, Indonesia \\ a,3 Mahasiswa Program Studi Diploma Tiga Farmasi, Universitas Muhammadiyah Mataram, Mataram, Indonesia \\ 1bq.tyee@gmail.com*; ekaranisuryaningsih742@gmail.com ${ }^{2} ;{ }^{3}$ rahman_apt@yahoo.co.id \\ *korespondensi penulis
}

\section{INFO ARTIKEL ABSTRAK}

Diterima :

4-12-2019

Disetujui :

12-12-2019

\section{Kata kunci :}

Pengetahuan;

Kepatuhan;

Tuberkulosis.

Semakin baik pengetahuan seseorang tentang pengobatan dan penyembuhan tuberkulosis maka kepatuhan dalam menjalani pengobatan juga akan baik sehingga keberhasilan pengobatan akan tercapai. Tujuan dari penelitian ini adalah untuk mengetahui tingkat pengetahuan dan kepatuhan pasien terhadap keberhasilan terapi tuberkulosis. Penelitian ini menggunakan observasional deskriptif dengan pendekatan cross secsional. Populasi pada penelitian ini adalah seluruh pasien tuberkulosis dengan kategori pasien pindahan, kambuh, putus berobat, dan gagal yang sedang menjalani pengobatan di instalasi rawat inap dan rawat jalan Rumah Sakit Umum Provinsi NTB, dengan jumlah sampel sebanyak 3 I responden. Alat ukur yang digunakan pada penelitian ini berupa kuisioner. Analisa yang digunakan adalah analisa univariat. Hasil dari penelitian ini menunjukkan bahwa tingkat pengetahuan pasien adalah 32,25\% berpengetahuan baik, 29,03\% berpengetahuan cukup, dan 38,70\% berpengetahuan kurang. Tingkat kepatuhan pasien adalah 38,70\% tinggi, 29,03\% sedang, dan 32,25\% rendah. Gambaran tingakat pengetahuan pasien tuberkulosis di Rumah Sakit Umum Provinsi NTB sebagian besar berpengetahuan kurang (38,70\%), dan gambaran tingkat kepatuhan pasien tuberkulosis sebagian besar dengan kepatuhan tinggi $(38,70 \%)$.

Keywords :

Knowledge;

Compliance;

Tuberculosis.

\section{ABSTRACT}

The better one's knowledge of treatment will also be good so that the succes of treatment will be achieved. The purpose of this study was to determine the level of knowledge and compliance of patients with the success of tuberculosis therapy. This study uses an observational descriptive cross sectional approach. The population in this study were all tuberculosis patients in the category of patients moving, relapsing, dropping out of treatment, and falling who were undergoing treatment in the inpatient and outpatient care of the NTB provincial public hospital, with a total sample of 3 I respondents. The measuring instrument used in this study was a questionnaire. The analysis used is univariate analysis. This result of this studyindicate that the level of knowledge of patients is $32,25 \%$ good knowledge, $29,03 \%$ have enough knowledge, $38,70 \%$ have less knowledge. The level of patient compliance was $38,70 \%$ high, 29,03\% moderate, and 32,25\% low. Description the level of knowledge of tuberculosis patients in NTB provincial general hospital most of the knowledge is lacking $(38,70 \%)$, and description the level of compliance of tuberculosis patients mostly with high adherence $(38,70 \%)$.

\section{PENDAHULUAN}

Tuberkulosis (TB) adalah suatu penyakit infeksi menular yang disebabkan oleh infeksi menular oleh bakteri Mycobacterium tuberkulosis. Sumber penularan yaitu pasien TB Bakteri Tahan
Asam (BTA) positif melalui percik renik dahak yang dikeluarkannya. Penyakit ini apabila tidak segera diobati atau pengobatannya tidak tuntas dapat menimbulkan komplikasi berbahaya hingga kematian (Kemenkes RI, 20I5). 
Menurut WHO Tuberkulosis merupakan penyakit yang menjadi perhatian global, dengan berbagai upaya pengendalian yang dilakukan, insiden dan kematian akibat Tuberkulosis telah menurun, namun Tuberkulosis diperkirakan masih menyerang 9,6 juta orang dan menyebabkan I,2 juta kematian pada tahun 20I4. India, Indonesia dan Cina merupakan negara dengan penderita Tuberkulosis terbanyak yaitu berturut-turut 23\%, I0\%, dan I0\% dari seluruh penderita di dunia (WHO, 20I5).

Menurut data RISKESDAS (Riset Kesehatan Dasar) 2018 untuk kasus TBC paru paru di provinsi Nusa Tenggara Barat adalah sebesar 0,4 \% sedangkan data yang diperoleh dari dinas Kesehatan NTB tentang jumlah kasus TBC pada tahun 2016 mencapai 5.828 orang. Sedangkan untuk tahun 2017 jumlah seluruh pasien TB adalah 6.644 orang, apabila dibandingkan dengan tahun 2016, maka kasus TB pada tahun 2017 mengalami peningkatan sebesar 14,04\% (Dinkes NTB, 2015). Prevalensi pasien Tuberkulosis berdasarkan data dari Rumah Sakit Umum Daerah Provinsi NTB pada tahun 2018 berjumlah 39I pasien.

Tujuan dari penelitian ini adalah untuk mengetahui tingkat pengetahuan pasien terhadap keberhasilan terapi tuberkulosis di Rumah Sakit Umum Daerah Provinsi NTB dan mengetahui tingkat kepatuhan pasien terhadap keberhasilan terapi tuberkulosis di Rumah Sakit Umum Daerah Provinsi NTB.

\section{METODE PENELITIAN}

Penelitian ini menggunakan observasional deskriptif dengan pendekatan cross secsional. Populasi pada penelitian ini adalah seluruh pasien tuberkulosis dengan kategori pasien pindahan, kambuh, putus berobat, dan gagal yang sedang menjalani pengobatan di instalasi rawat inap dan rawat jalan Rumah Sakit Umum Provinsi NTB. Sampel pada penelitian ini adalah pasien tuberrkulosis yang sedang menjalani pengobatan di instalasi rawat inap dan rawat jalan Rumah Sakit Umum Provinsi NTB periode Juli-Agustus 2019. Penelitian ini dilakukan di Rumah Sakit Umum Provinsi Nusa Tenggara Barat yang beralamatkan di Jalan Prabu Rangkasari, Dasan Cermen, Sandubaya, Kota Mataram.

I. Dalam penelitian ini, alat yang digunakan untuk mengumpulkan data berupa kuesioner yang telah disesuaikan dengan tujuan penelitian dan juga berpacu pada kerangka konsep penelitian yang dibuat.

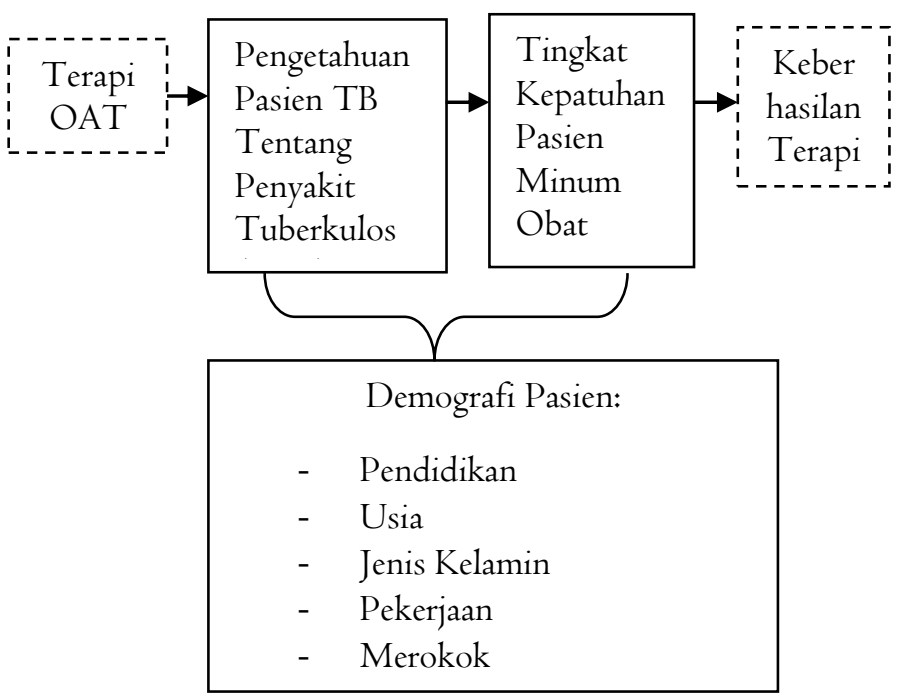

Keterangan:

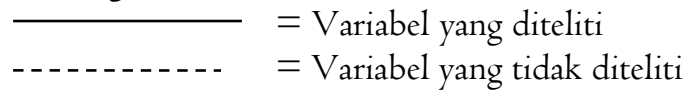

Gambar I. Kerangka Konsep Penelitian

2. Jalannya penelitian yang dilakukan pada peneliti ini yaitu sebagai berikut:

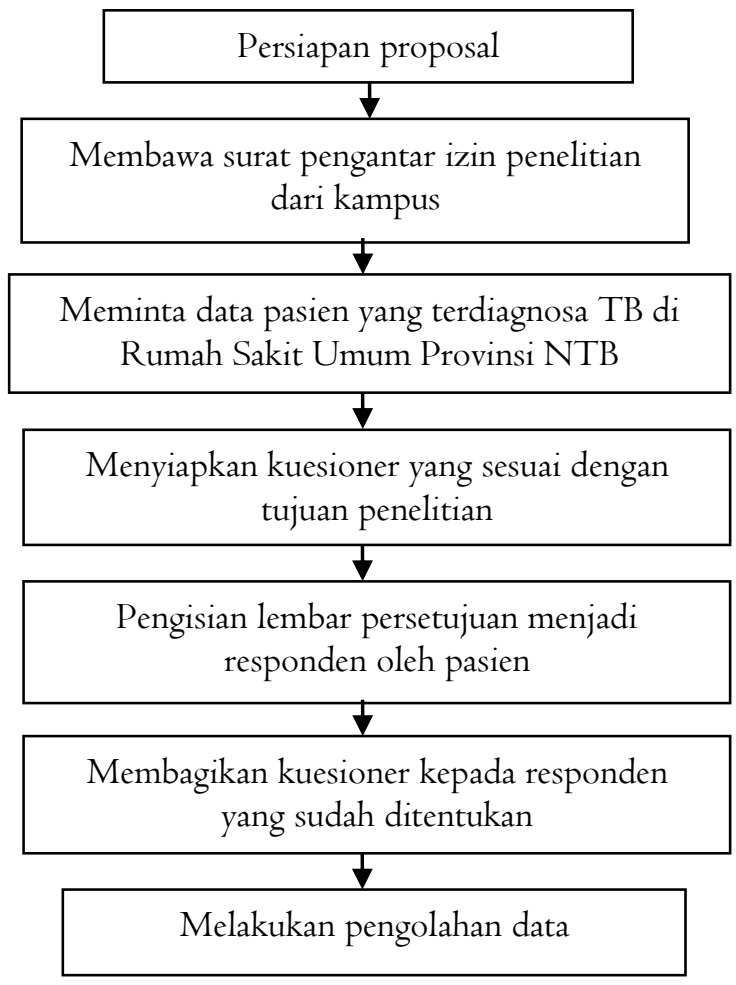

Gambar 2. Alur Penelitian

\section{HASIL DAN PEMBAHASAN}

Responden pada penelitian ini didapat sebanyak 3I orang yang telah memenuhi kriteria inklusi. Penilaian tingkat pengetahuan dan kepatuhan berdasarkan karakteristik pasien dilakukan dengan cara pengelompokkan pasien 
berdasarkan karakteristik jenis kelamin, usia, pendidikan, dan pekerjaan. Karakteristik pasien dapat dilihat pada tabel berikut ini:

\section{Gambaran Pengetahuan Pasien Tuberkulosis di RSUP NTB Brdasarkan Karakteristik Pasien}

Penilaian terhadap pengetahuan pasien berdasarkan atas kemampuan pasien dalam menjawab pertanyaan-pertanyaan mengenai penyakit tuberkulosis, yang terdiri dari penyebab, gejala, dan penularan penyakit tuberkulosis.

\begin{tabular}{|c|c|c|c|}
\hline \multirow{2}{*}{$\begin{array}{l}\text { Status } \\
\text { Pasien }\end{array}$} & \multicolumn{3}{|c|}{ Tingkat Pengetahuan Pasien (\%) } \\
\hline & Baik & Cukup & Kurang \\
\hline $\begin{array}{l}\text { Pendidik } \\
\text { an: } \\
\text { SD } \\
\text { SMP } \\
\text { SMA } \\
\text { PT }\end{array}$ & $\begin{array}{l}0(0 \%) \\
0(0 \%) \\
2(6,45 \%) \\
8(25,80 \%)\end{array}$ & $\begin{array}{l}0(0 \%) \\
0(0 \%) \\
8(25,80 \%) \\
I(3,22 \%)\end{array}$ & $\begin{array}{l}6 \\
(\mathrm{I} 9,35 \% \\
) \\
4 \\
(\mathrm{I} 2,90 \% \\
) \\
2 \\
(6,45 \%) \\
0(0 \%)\end{array}$ \\
\hline $\begin{array}{l}\text { Usia: } \\
\text { Remaja } \\
\text { akhir } \\
\text { Dewasa } \\
\text { Lansia }\end{array}$ & $\begin{array}{l}\text { I }(3,22 \%) \\
6(19,35 \%) \\
3(9,67 \%)\end{array}$ & $\begin{array}{l}2(6,45 \%) \\
6(19,35 \%) \\
I(3,22 \%)\end{array}$ & $\begin{array}{l}0 \\
(0 \%) \\
4 \\
(\mathrm{I} 2,9 \\
0 \%) \\
8 \\
(25,8 \\
0 \%)\end{array}$ \\
\hline $\begin{array}{l}\text { Jenis } \\
\text { Kelamin: } \\
\text { Laki-laki } \\
\text { Perempu } \\
\text { an }\end{array}$ & $\begin{array}{l}9(29,03 \%) \\
I(3,22 \%)\end{array}$ & $\begin{array}{l}4(\mathrm{I} 2,90 \%) \\
5(16, \mathrm{I} 2 \%)\end{array}$ & $\begin{array}{l}7 \\
(22,5 \\
8 \%) \\
5 \\
(16,1 \\
2 \%)\end{array}$ \\
\hline $\begin{array}{l}\text { Pekerjaan } \\
: \\
\text { Swasta } \\
\text { Wirausa } \\
\text { ha PNS } \\
\text { Dan lain- } \\
\text { lain }\end{array}$ & $\begin{array}{l}5(16,12 \%) \\
0(0 \%) \\
4(12,90 \%) \\
I(3,22 \%)\end{array}$ & $\begin{array}{l}4(12,90 \%) \\
\text { I }(3,22 \%) \\
0(0 \%) \\
4(12,90 \%)\end{array}$ & \begin{tabular}{|l} 
\\
$(3,22$ \\
$\%)$ \\
2 \\
$(6,45$ \\
$\%)$ \\
0
\end{tabular} \\
\hline
\end{tabular}

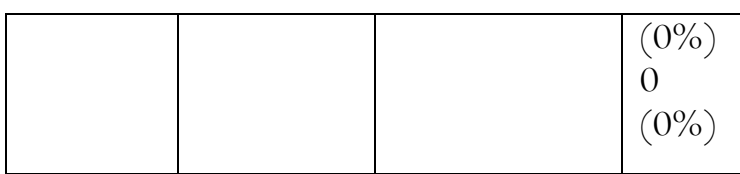

Berdasarkan hasil penelitian didapatkan bahwa pasien di Rumah Sakit Umum Provinsi NTB, yang mana pendidikan terakhir sebagian besar adalah tingkat SMA dengan tingkat pengetahuan cukup, karena pengetahuan seseorang didukung oleh latar belakang pendidikan, semakin lama seseorang dalam menempuh pendidikan maka akan semakin baik tingkat pengetahuan seseorang.

Berdasarkan usia, sebagian besar pasien berusia dewasa karena pada usia dewasa dengan pengetahuan baik dan cukup, hal ini karena usia dewasa memiliki daya tangkap dan pola pikir yang sedang bekerja serta individu lebih berperan aktif dalam mencari pengetahuan sehingga pada usia ini memiliki waktu untuk belajar, berlatih, dan membaca.

Berdasarkan jenis kelamin, pasien tuberkulosis sebagian besar berjenis kelamin laki-laki dengan tingkat pengetahuan baik karena laki-laki mempunyai pergaulan yang luas dan mayoritas lakilaki mempunyai kebiasaan merokok sehingga besar kemungkinan mudah terjangkit penyakit tuberkulosis.

Pada penelitian ini, sebagian besar pasien di Rumah Sakit Umum Provinsi NTB bekerja sebagai buruh, petani, pengurus rumah tangga (dan lainlain). Pekerjaan yang berada di lingkungan yang berdebu akan meningkatkan risiko terjadinya gangguan pada saluran pernapasan. Pekerjaan di tempat yang lembab serta dengan pencahayaan dan ventilasi yang kurang baik, meningkatkan risiko terjadinya penularan di tempat kerja (Suryo, 2010).

\section{Gambaran Pengetahuan Pasien Tuberkulosis Secara Umum}

Berdasarkan hasil penelitian yang dilakukan di Rumah Sakit Umum Provinsi NTB, didapatkan hasil tingkat pengetahuan pasien tuberkulosis secara umum:

\begin{tabular}{|l|c|c|}
\hline Pengetahuan Pasien & Jumlah & Persentase (\%) \\
\hline Baik & I0 & 32,25 \\
Cukup & 9 & 29,03 \\
Kurang & I2 & 38,70 \\
\hline Total & \multicolumn{2}{|c|}{31} \\
\hline
\end{tabular}

Berdasarkan hasil penelitian pada tabel di atas, gambaran tingkat pengetahuan pasien tuberkulosis 
secara umum, di Rumah Sakit Umum Provinsi NTB didapatkan bahwa pasien berpengetahuan baik sebanyak I0 pasien (32,25\%), pasien berpengetahuan cukup sebanyak 9 pasien (29,03\%), dan pasien berpengetahuan kurang sebanyak 12 pasien (38,70\%). Tingkat pengetahuan pasien tuberkulosis di Rumah Sakit Umum Provinsi NTB sebagian besar berpengetahuan kurang.

\section{Gambaran Kepatuhan Pasien Tuberkulosis di RSUP NTB Berdasarkan Karakteristik Pasien}

Berdasarkan hasil penelitian, penilaian terhadap tingkat kepatuhan responden berdasarkan atas menjawab pertanyaan-pertanyaan mengenai kepatuhan dalam menjalani pengobatan tuberkulosis didapatkan hasil sebagai berikut:

\begin{tabular}{|c|c|c|c|}
\hline \multirow{2}{*}{$\begin{array}{c}\text { Status } \\
\text { Respon } \\
\text { den }\end{array}$} & \multicolumn{3}{|c|}{ Tingkat Pengetahuan (\%) } \\
\hline & Tinggi & Sedang & Rendah \\
\hline $\begin{array}{l}\text { Pendidi } \\
\text { ka: } \\
\text { SD } \\
\text { SMP } \\
\text { SMA } \\
\text { PT }\end{array}$ & $\begin{array}{l}0(0) \\
\mathrm{I}(3,22) \\
3(9,67) \\
8(25,80)\end{array}$ & $\begin{array}{l}\mathrm{I}(3,22) \\
\mathrm{O}(0) \\
7(22,58) \\
\mathrm{I}(3,22)\end{array}$ & $\begin{array}{l}5(16,12) \\
3(9,67) \\
2(6,45) \\
0(0)\end{array}$ \\
\hline $\begin{array}{l}\text { Usia: } \\
\text { Remaja } \\
\text { akhir } \\
\text { Dewasa } \\
\text { Lansia } \\
\end{array}$ & $\begin{array}{l}I(3,22) \\
9(29,03) \\
2(6,45)\end{array}$ & $\begin{array}{l}2(6,45) \\
4(12,90) \\
3(9,67)\end{array}$ & $\begin{array}{l}0(0) \\
3(9,67) \\
7(22,58)\end{array}$ \\
\hline $\begin{array}{l}\text { Jenis } \\
\text { Kelami } \\
\text { n: } \\
\text { Laki- } \\
\text { laki } \\
\text { Peremp } \\
\text { uan }\end{array}$ & $\begin{array}{l}\operatorname{IO}(32,25) \\
2(6,45)\end{array}$ & $\begin{array}{l}5(16,12) \\
6(19,35)\end{array}$ & $\begin{array}{l}5(16,12) \\
3(9,67)\end{array}$ \\
\hline $\begin{array}{l}\text { Pekerja } \\
\text { an: } \\
\text { Swasta } \\
\text { Wiraus } \\
\text { aha } \\
\text { PNS } \\
\text { Dan } \\
\text { lain- } \\
\text { lain } \\
\end{array}$ & $\begin{array}{l}6(19,35) \\
0(0) \\
3(9,67) \\
3(9,67)\end{array}$ & $\begin{array}{l}3(9,67) \\
I(3,22) \\
I(3,22) \\
4(12,90)\end{array}$ & $\begin{array}{l}\mathrm{I}(3,22) \\
2(6,45) \\
0(0) \\
7(22,58)\end{array}$ \\
\hline
\end{tabular}

Berdasarkan hasil penelitian didapatkan bahwa jumlah pasien dengan pendidikan terakhir perguruan tinggi, tingkat kepatuhannya cenderung lebih tinggi yaitu 8 orang pasien $(25,80 \%)$ dibandingkan pasien dengan pendidikan terakhir SD dan SMP yang tingkat kepatuhannya cenderung lebih rendah. Untuk pasien dengan pendidikan terakhir SMA tingkat kepatuhannya cenderung sedang yaitu 7 orang pasien (22,58\%). Hal ini dapat terjadi karena tingkat pendidikan formal merupakan landasan seseorang dalam berbuat sesuatu, membuat lebih mengerti dan memahami sesuatu, atau menerima dan menolak sesuatu, sehingga tingkat pendidikan seseorang akan mempengaruhi pengetahuan seseorang. Pasien dengan pendidikan yang tinggi lebih patuh terhadap pengobatan tuberkulosis dibandingkan pasien dengan pendidikan rendah.

Berdasarkan usia pasien, pada penelitian ini didapatkan bahwa pasien dengan usia dewasa cenderung lebih patuh, yang mana tingkat kepatuhannya termasuk kategori tinggi yaitu 9 orang pasien $(29,03 \%)$. Untuk usia remaja akhir tingkat kepatuhannya cenderung sedang yaitu 2 orang pasien $(6,45 \%)$, dan untuk usia lanjut tingkat kepatuhannya cenderung rendah yaitu 7 orang pasien (22,58\%). Pada penelitian Kondoy (2013), mengatakan bahwa umur responden tidak berhubungan dengan kepatuhan berobat pasien tuberkulosis, karena semua pasien tuberkulosis ingin sembuh dari penyakitnya sehingga patuh untuk mengikuti panduan obat yang diberikan walaupun memakan waktu yang lama.

Berdasarkan jenis kelamin pasien, pada penelitian ini didapatkan bahwa pasien dengan jenis kelamin laki-laki cenderung memiliki tingkat kepatuhan tinggi dibandingkan dengan perempuan, yang mana laki-laki berjumlah 10 orang pasien (32,25\%), sedangkan perempuan berjumlah 2 orang pasien (6,45\%). Menurut Kondoy (2013), jenis kelamin tidak mempunyai hubungan dengan tingkat kepatuhan berobat pasien tuberkulosis.

Berdasarkan hasil penelitian yang didapatkan sebagian besar pasien tuberkulosis di Rumah Sakit Umum Provinsi NTB bekerja sebagai buruh, petani, dan pengurus runah tangga (dan lain-lain) cenderung memiliki tingkat kepatuhan yang rendah yaitu sejumlah 7 orang pasien (22,58\%), sedangkan pasien pekerja swasta cenderung lebih memiliki tingkat kepatuhan tinggi yaitu sejumlah 6 orang pasien (I9,35\%). Pada pasien pekerja wirausaha cenderung lebih memiliki tingkat kepatuhan rendah yaitu sejumlah 2 orang pasien (6,45\%), dan pasien pekerja PNS cenderung memiliki tingkat kepatuhan tinggi yaitu sejumlah 3 orang pasien (9,67\%). Salah satu faktor struktur sosial yaitu pekerjaan akan mempengaruhi pemanfaatan pelayanan kesehatan, pekerjaan seseorang dapat mencerminkan sedikit banyaknya informasi yang diterima, informasi tersebut akan membantu seseorang dalam mengambil keputusan untuk memanfaatkan pelayanan kesehatan yang ada. 


\section{Gambaran Kepatuhan Pasien Tuberkulosis Secara Umum}

Berdasarkan hasil penelitian yang dilakukan di Rumah Sakit Umum Provinsi NTB, didapatkan hasil tingkat kepatuhan pasien tuberkulosis secara umum seperti pada tabel berikut:

\begin{tabular}{|l|c|c|}
\hline $\begin{array}{c}\text { Kepatuhan } \\
\text { Pasien }\end{array}$ & Jumlah & $\begin{array}{c}\text { Persentase } \\
\text { (\%) }\end{array}$ \\
\hline Tinggi & I2 & 38,70 \\
Sedang & 9 & 29,03 \\
Rendah & I0 & 32,25 \\
\hline Total & 3I \\
\hline
\end{tabular}

Berdasarkan hasil penelitian pada tabel $4.5 \mathrm{di}$ atas, gambaran tingkat kepatuhan pasien tuberkulosis secara umum, di Rumah Sakit Umum Provinsi NTB didapatkan bahwa pasien dengan kepatuhan tinggi sebanyak 12 pasien $(38,70 \%)$, pasien dengan kepatuhan sedang sebanyak 9 pasien $(29,03 \%)$, dan pasien dengan kepatuhan rendah sebanyak 10 pasien $(32,25 \%)$. Tingkat kepatuhan pasien tuberkulosis di Rumah Sakit Umum Provinsi NTB sebagian besar pasien dengan kepatuhan tinggi.

\section{SIMPULAN}

1. Berdasarkan hasil penelitian didapatkan bahwa, gambaran tingkat pengetahuan pasien tuberkulosis di Rumah Sakit Umum Provinsi NTB sebagian besar pengetahuan kurang sebanyak I2 pasien (38,70\%).

2. Berdasarkan hasil penelitian didapatkan bahwa, gambaran tingkat kepatuhan pasien tuberkulosis di Rumah Sakit Umum Provinsi NTB sebagian besar pasien dengan kepatuhan tinggi sebanyak 12 pasien $(38,70 \%)$.

\section{UCAPAN TERIMA KASIH}

Penulis mengucapkan terimakasih kepada seluruh responden yang bersedia ikut serta dalam penelitian ini.

\section{REFERENSI}

Aditama, H. P., \& Aris, A. (2013). Hubungan Pengetahuan dan Motivasi Pasien TBC (Tuberkulosis) dengan Kepatuhan Berobat Pasien TBC yang Berobat di UPT Puskesmas Mantup Kabupaten Lamongan. Jawa Timur.

Adiwia, Kurniawan. 2012. Gambaran Tingkat Pengetahuan Pasien TB.Paru Rencana
Pulang Tentang Penyakit TB.Paru di Ruang Rawat Inap RS. Paru DR.M.Goenawan Partowidigdo. Jakarta: Universitas Indonesia.

Arikunto. 2006. Prosedur Penelitian Suatu Pendekatan Praktek. Jakarta: PT. Rineka Cipta

Arifin, Zainal. 2008. Dasar-dasar Penulisan Karya Ilmiah. Jakarta: Gasindo.

CMAG. 2006. Case Management Adherence Guideline, Case Management Society of America, USA, 8, 4-15, 2I, 28, 33, 35, 40-4I.

Departemen Kesehatan R.I. 2005. Rencana Strategi Departemen Kesehatan. Jakarta; Depkes RI.

Depkes RI. 2007. Keputusan Mentri Kesehatan RI No: 900/Menkes/VII/2007. Konsep Asuhan Kebidanan. Jakarta.

Deparetemen Kesehatan RI.2008. Profil Kesehatan Indonesia 2007. Jakarta; Depkes RI Jakarta.

Departemen Kesehatan RI. 20I2. Profil Kesehatan Republik Indonesia Tahun 2012. (Online). Tersedia: http://www.depkes.go.id. I3 November 2013.

Depkes RI. 2016. Info Tuberkulosis: Temukan Obat Sampai Sembuh. Jakarta: Depkes RI.

Dinas Kesehatan Kabupaten/Kota se-Propinsi NTB, Profil Kesehatan Kabupaten atau Kota, tahun 2015.

Dinas Kesehatan, NTB. 20I7. Profil Kesehatan Provinsi NTB Tahun 20I7. NTB; Dinas Kesehatan NTB.

Erawatyningsih. E., Purwanta,\& Subekti, H. $\begin{array}{lrr}\text { (2009). Faktor-Faktor } & \text { yang } \\ \text { Mempengaruhi Ketidakpatuhan } & \text { Factors } \\ \text { Affecting Incompliance } & \text { With } \\ \text { Medication, 25 (3), I I7-I24. } & \end{array}$

Gillespie, S. \& Bamford, K., 2009, Mikrobiolgi Medis dan Infeksi, edisi 3, Jakarta, Erlangga.

Himawan, A. B., Hadisaputro, S., \& Suprihati. (20I5). Berbagai Faktor Resiko Kejadian TB Paru Drop Out.

Kementrian Kesehatan RI. 20II. Pedoman Pembinaan Perilaku Hidup Bersih dan Sehat. Jakarta; Kementrian Kesehatan RI.

Kementrian Kesehatan. 20I2. Pedoman Penanggulangan Infeksi Saluran Pernafasan Akut. Jakarta; Kementrian Kesehatan RI. 
Kemenkes RI. 20I5. Laporan Profil Kesehatan Indonesia. Jakarta: Kementrian Kesehatan RI.

Kondoy, Priska PH. 2014. Faktor-faktor yang berhubungan Dengan Kepatuhan Berobat Pasien Tuberkulosis Paru di Lima Puskesmas di Kota Manado. Manado: FK Universitas Sam Ratulangi.

Manalu, H.S.P., 2010, Faktor-Faktor yang Mempengaruhi Kejadian TB Paru dan Upaya Penanggulangannya, Jurnal Ekologi Kesehatan Vol. 9 No.4, Desember 2010: I340-I346.

Morisky, DE., Ang, A., Krousel-Wood, M., Ward, HJ., (2008), Predictive Validity Of Medication Adherence Measure In An Outpatient Setting, J Clin Hypertens, IO(5):348-354.

Notoatmodjo, Soekidjo. 2005. Promosi Kesehatan Teori dan Aplikasinya. Jakarta; Rineka Cipta.

Notoatmodjo, Soekidjo.2007. Kesehatan Masyarakat Ilmu dan Seni. Jakarta; Rineka Cipta.

Notoatmodjo, Soekidjo. 2010. Metodologi Penelitian Kesehatan. Jakarta: Rineka Cipta.

Notoatmodjo S. 20I4. Ilmu Perilaku Kesehatan. Jakarta: Rineka Cipta.

Panjaitan, R. Pharmaceutical Care Untuk Pasien Penyakit Artritis Rematik. Jakarta: Direktorat Bina Farmasi Komunitas dan Klini, Ditjen Bina Kefarmasian dan Alat Kesehatan, Departemen Kesehatan; 2006.

Prasetya, J. (2009). Hubungan Motivasi Pasien TB Paru dengan Kepatuhan dalam Mengikuti Program Pengobatan Sistem DOTS di Wilayah Puskesmas Genuk, 46-53.

Price, S. A., dan Wilson, L.M., 2005, Patofisiologi: Konsep Klinis ProsesProses Penyakit, Edisi 6, vol.2, diterjemahkan oleh Pendit, B.U., Hartanto, H., Wulansari, p., Maharani, D.A., Penerbit Buku Kedokteran EGC, Jakarta.

Pujiastuti, SR. 2016. Gambaran Pengetahuan Pasien Tentang Tuberkulosis (TBC) di Wilayah Kerja Puskesmas Andong Boyolali. Surakarta: STKes Kusuma Husada.

Riset Kesehatan Dasar (Riskesdas) (2018). Badan Penelitian dan Pengembangan Kesehatan Kementrian RI tahun 2018. http://www.depkes.go.id/resources/dow nload/infoterkini/materirakorpop2018/
hasil\%20Riskesdas\%202018.pdf

Diakses Agustus 2018.

Sugiyono. 2010. Metode Penelitian Kuantitatif Kualitatif. Bandung: CV Alfa Beta

Suryo, Joko. 2010. Penyembuh Gangguan Sistem Pernafasan. Yogyakarta; B First (PT Bentang Pustaka).

Wibowo, AT. 2016. Karakteristik TB Paru Dewasa di Balai Besar Kesehatan Paru Masyarakat Surakarta Tahun 2015. Surakarta; Universitas Muhammadiyah Surakarta.

Widianingrum, TR. 2017. Hubungan Pengetahuan dan Motivasi Dengan Kepatuhan Minum Obat Anti Tuberkulosis Pada Pasien TB di Wilayah Kerja Puskesmas Perak Timur Surabaya. Jawa Timur; Universitas Airlangga.

Widoyono. 2008. Penyakit Tropis, Epidemiologi, Penularan, Pencegahan dan Pemberantasannya. Jakarta; Erlangga.

World Health Organization. 2003. Treatment of Tuberculosis Guidlines For National Programmers, 3rd Edition. Geneva

World Health Organization. WHO Report 2013-Global Tuberculosis Control. www.who.int/tb/data. Diunduh tanggal 3I Oktober 2013.

World Health Organization. 20I4. Global Tuberculosis Report 2014. Switzerland.

World Health Organization. 2015. Global Tuberculosis Report. Switzerland. 